\title{
Effect of sulphate concentration and sulphide desorption on the combined removal of organic matter and sulphate from wastewaters using expanded granular sludge bed (EGSB) reactors
}

\author{
Freddy Valdés \\ Departamento de Ingeniería Química \\ Facultad de Ingeniería, Ciencias y Administración \\ Universidad de La Frontera \\ Casilla 54-D, Temuco, Chile \\ Tel: 5645325472 \\ Fax: 5645325053 \\ Edmundo Muñoz \\ Departamento de Ingeniería Química \\ Facultad de Ingeniería, Ciencias y Administración \\ Universidad de La Frontera \\ Casilla 54-D, Temuco, Chile \\ Tel: 5645325472 \\ Fax: 5645325053

\section{Rolando Chamy} \\ Escuela de Ingeniería Bioquímica \\ Facultad de Ingeniería \\ Pontificia Universidad Católica de Valparaíso \\ General Cruz 34 \\ Valparaíso, Chile \\ Tel: 5632273651 \\ Fax: 5632273803 \\ E-mail: rchamy@ucv.cl

\section{Gonzalo Ruiz} \\ Escuela de Ingeniería Bioquímica \\ Facultad de Ingeniería \\ Pontificia Universidad Católica de Valparaíso \\ General Cruz 34 \\ Valparaíso, Chile \\ Tel: 5632273651 \\ Fax: 5632273803

\section{Christian Vergara} \\ Departamento de Ingeniería Química \\ Facultad de Ingeniería, Ciencias y Administración \\ Universidad de La Frontera \\ Casilla 54-D, Temuco, Chile \\ Tel: 5645325472 \\ Fax: 5645325053 \\ David Jeison* \\ Departamento de Ingeniería Química \\ Facultad de Ingeniería, Ciencias y Administración \\ Universidad de La Frontera \\ Casilla 54-D, Temuco, Chile \\ Tel: 5645325472 \\ Fax: 5645325053 \\ E-mail: djeison@ufro.cl
}

Financial support: Research Project FONDECYT 1020201.

Keywords: anaerobic digestion, EGSB, sulphate reduction, sulphide.

*Corresponding author 


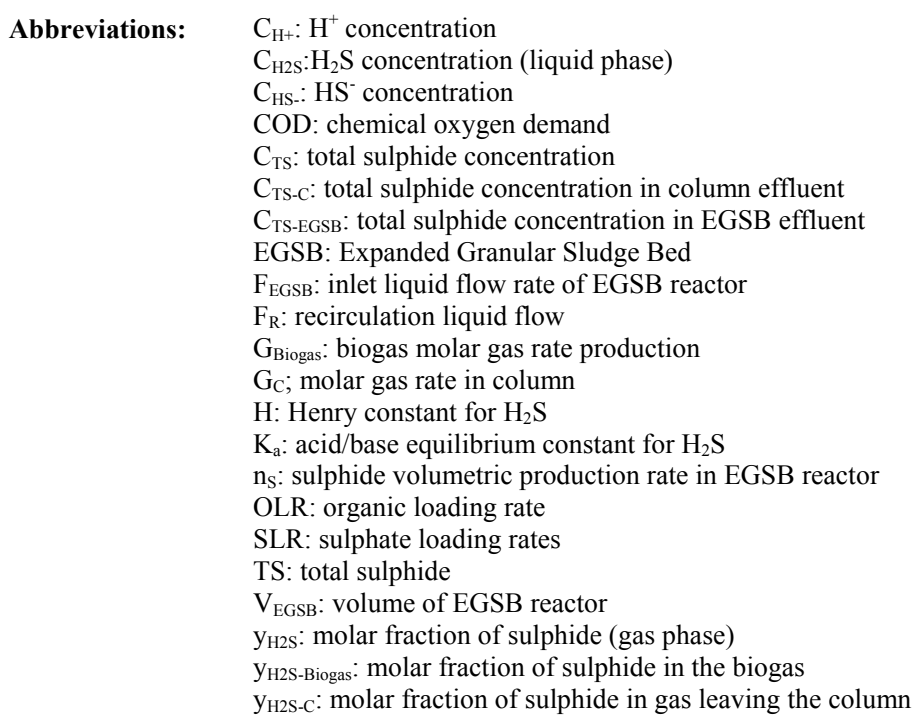

During the application of anaerobic processes to high sulphate concentration wastewaters, operational problems are expected due to the occurrence of sulphate reduction. Sulphide production reduces effluent quality and may produce inhibition. The application of Expanded Granular Sludge Bed (EGSB) reactors for the combined removal of organic matter and sulphate was studied at different $\mathrm{COD} / \mathrm{sulphate}$ and 3 values of pH. During the EGSB reactor operation, most of the sulphide remains in the liquid phase reducing effluent quality. The inclusion of a desorption column in the recirculation of the EGSB reactor promotes mass transfer to the gas phase, reducing the sulphide concentration in the liquid phase, significantly decreasing the chemical oxygen demand of the effluent.

During the last 30 years, the anaerobic process has been successfully used at big scale for the treatment of wastewaters. Nowadays, it can be considered as an established technology and it is successfully used for the treatment of sewage and many kinds of industrial wastewaters. It offers the possibility of an efficient treatment with low operational costs (Lettinga et al. 1997). However, during anaerobic treatment of high sulphate concentration wastewaters, operational problems may arise as a result of the formation of hydrogen sulphide, produced due to sulphate reduction.

Sulphate-reducing bacteria form a group of generally anaerobic microorganisms that are able to use sulphate as final electron acceptor, for the molecular oxidation of $\mathrm{H}_{2}$ and a wide variety of organic compounds, like volatile fatty acids, ethanol, methanol, fumarate, among others (Widdel, 1988). Unlike acetogenic bacteria, sulphate-reducing microorganisms do not require low $\mathrm{H}_{2}$ concentration for their growth, which gives them a thermodynamic advantage. Besides, in absence of sulphate, they can use fermentative or acetogenic pathways to produce energy (Raskin et al. 1996). The competition established between sulphate reducing and methanogenic and acetogenic microorganisms for the electron donor (organic matter and $\mathrm{H}_{2}$ ) modifies the traditional scheme of anaerobic digestion, and can limit organic matter removal (Visser et al. 1993; O'Flaherty et al. 1998). Sulphur presence inhibits both sulphate reducer and methanogenic bacteria. Inhibition seems to be non-competitive, which is indeed the most common mechanism for inorganic compounds (Maillacheruvu and Parkin, 1996). The non-ionized form of sulphide is the main responsible for the inhibition (Speece, 1996), therefore $\mathrm{pH}$ plays a fundamental role, since it defines the equilibrium between ionized and non-ionized sulphide forms. Sulphide pKa is very close to 7 , which corresponds to the operation $\mathrm{pH}$ of anaerobic digesters. Therefore, small changes in $\mathrm{pH}$ will notoriously affect sulphide acid/base equilibrium.

Several industrial processes that use sulphuric acid in high amounts, or sulphate rich substrates, generate wastewaters with high sulphate and organic matter content. This is the case of fermentation and marine food processing industries. Both pollutants can also be found in productive activities that use reduced sulphur compounds like tanneries and Kraft pulp bleaching.

The impact of sulphate over anaerobic digestion of organic matter depends on the sulphate concentration, and specifically on the ratio between chemical oxygen demand (COD) and sulphate. Values of $\mathrm{COD} / \mathrm{SO}_{4}{ }^{-2}$ over 10 should not represent a threat to process stability (Rinzema and Lettinga, 1988; Speece, 1996). Below this value, sulphate reduction becomes important and a large fraction of the organic matter begins to be consumed through sulphate reduction.

Sulphide generation in anaerobic wastewater treatment produces several difficulties: reduction in the methane production, odour problems, corrosion, increase of effluent chemical oxygen demand, among others (Buisman et al. 1991; Li et al. 1996). However, despite these difficulties, 
Table 1. Operation periods for the EGSB reactor, without desorption column.

\begin{tabular}{|c|c|c|c|c|}
\hline Operation period & $\mathrm{SO}_{4}^{-2}(\mathrm{mg} / \mathrm{l})$ & $\mathrm{pH}$ & $\mathrm{COD} / \mathrm{SO}_{4}{ }^{-2}$ & $\begin{array}{c}\text { Sulphate loading rate } \\
\text { (g/Ld) }\end{array}$ \\
\hline 1 & 150 & 6.5 & 28 & 0.6 \\
\hline 2 & 150 & 7.0 & 28 & 0.6 \\
\hline 3 & 150 & 7.5 & 28 & 0.6 \\
\hline 4 & 350 & 7.5 & 12 & 1.4 \\
\hline 5 & 350 & 7.0 & 12 & 1.4 \\
\hline 6 & 350 & 6.5 & 12 & 1.4 \\
\hline 7 & 600 & 7.5 & 7 & 2.4 \\
\hline 8 & 600 & 7.0 & 7 & 2.4 \\
\hline 9 & 600 & 6.5 & 7 & 2.4 \\
\hline $10^{(*)}$ & 600 & 6.5 & 7 & 2.4 \\
\hline 11 & 900 & 7.5 & 4.7 & 3.6 \\
\hline 12 & 900 & 7.0 & 4.7 & 3.6 \\
\hline 13 & 900 & 6.5 & 4.7 & 3.6 \\
\hline $14^{(*)}$ & 900 & 6.5 & 4.7 & 3.6 \\
\hline
\end{tabular}

$\left({ }^{\star}\right)$ Indicates a $V_{s}$ of $8.5 \mathrm{~m} / \mathrm{h}$.

For the rest of the experiments Vs was $6.5 \mathrm{~m} / \mathrm{h}$

sulphate reduction can be used as a tool for sulphate removal. If adequate measures are undertaken to control sulphide concentration, anaerobic technology may be used as a tool to remove both sulphate and organic matter, becoming a biotechnological alternative for the combined removal of both pollutants.

The present research is focused on the study of Expanded Granular Sludge Bed (EGSB) reactors for the combined removal of sulphate and organic matter from wastewaters. Digester high mixing level may be useful to enhance sulphide transfer to the gaseous phase, reducing inhibition risks. Hydrogen sulphide can then be removed from the gas phase by a chemical process. The effect of attaching a desorption column to the reactor recirculation in order to improve sulphide transfer to the biogas, was also evaluated. Mass balances for sulphur were performed and the effect of operational conditions like $\mathrm{pH}$ and $\mathrm{COD} / \mathrm{SO}_{4}{ }^{-2}$ ratio were analyzed.

\section{MATERIALS AND METHODS}

\section{Experimental set-up}

A 4.5 L effective-volume EGSB reactor was used to conduct this study. Reactor diameter and height were 160 and $6 \mathrm{~cm}$, respectively. A $2.5 \mathrm{~L}$ head was attached on top of the reactor to improve biomass retention. Head volume was not taken into account for organic or sulphate loading rates (OLR, SLR) calculations, since it is considered only to enhance sludge retention. $\mathrm{pH}$ was automatically controlled by the addition of a $80 \mathrm{~g} / \mathrm{L} \mathrm{NaOH}$ solution. The $\mathrm{pH}$ sensor was placed in the recirculation line. Reactor temperature was kept at $25^{\circ} \mathrm{C}$. Digester feed and recirculation were performed by peristaltic pumps. Seed sludge was obtained from a full-scale UASB reactor treating brewery wastewater. The reactor was fed with synthetic wastewater based on diluted wine as COD source. Sodium sulphate was added to the feed in order to get the desired sulphate concentration. During part of the reactor operation, a $0.8 \mathrm{~L}$ effective-volume desorption column (bubbling type) was placed in the recirculation line, to physically remove sulphide from the liquid through its transfer to the gaseous 


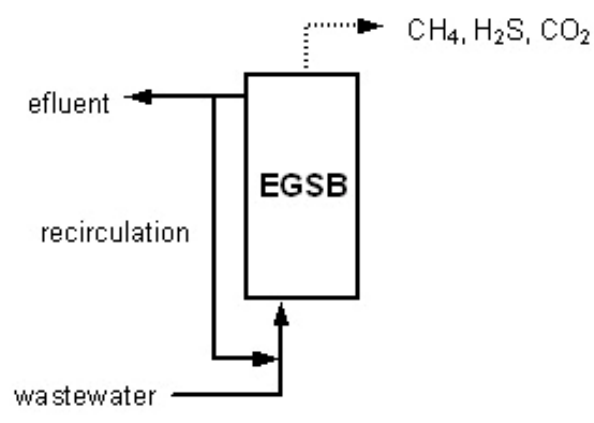

(a)

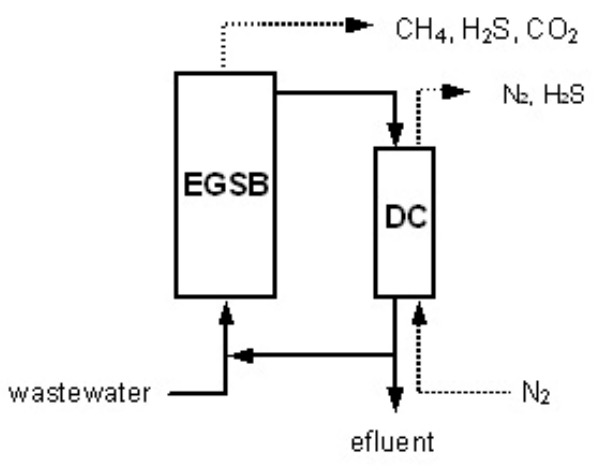

(b)

Figure 1. Schematic representation of tested configurations.

(a) EGSB reactor in absence of desorption column.

(b) EGSB reactor coupled with a desorption column to control sulphide concentration.

phase. Nitrogen gas was used to promote sulphide desorption at a rate of $144 \mathrm{~L} / \mathrm{d}$ (Figure 1). Nitrogen was used only to simulate a biogas stream that has passed through a physical-chemical step to remove $\mathrm{H}_{2} \mathrm{~S}$.

\section{Analytical methods}

COD and sulphate were measured by closed reflux dichromate oxidation and turbidimetry respectively, according to Standard Methods (Clescerl et al. 1999). Sulphide was determined using an ion selective electrode (Orion 96-16). Gas composition was determined using gas detection tube kits (Rae Systems).

\section{Reactor operation}

The EGSB reactor was started-up in absence of sulphate, and was operated for 6 weeks prior to start feeding sulphate. The reactor operation was divided in two phases. During first one, sulphate concentration was increased in steps as shown in Table 1. At each level, three values of $\mathrm{pH}$ were tested. During periods 10 and 14, liquid superficial velocity $\left(\mathrm{V}_{\mathrm{S}}\right)$ was increased adjusting the recirculation rate. During the second stage of operation, a desorption column was placed on the recirculation line as shown in Figure 1. Effluent was collected at the column outlet. Three levels of sulphate concentration were tested, at the same $3 \mathrm{pH}$ values as the first phase (Table 2). Each condition was kept until no significant changes in COD, sulphate, or sulphur concentrations in the effluent were observed. Inlet COD concentration and OLR were kept at $4200 \mathrm{mg} \mathrm{COD} / \mathrm{L}$ and $17 \mathrm{~kg} \mathrm{COD} / \mathrm{m}^{3} \cdot \mathrm{d}$, respectively during the whole reactor operation.

\section{Mass balance calculations}

In order to establish maximum levels of sulphide mass transfer to the gas phase, mass balance calculations assuming equilibrium conditions were performed, for both configurations presented in Figure 1. The relation between $\mathrm{H}_{2} \mathrm{~S}$ and $\mathrm{HS}^{-}$in the liquid phase is determined by the acidbase equilibrium constant and the $\mathrm{pH}$ :

$$
\mathrm{H}_{2} \mathrm{~S} \leftrightarrow \mathrm{HS}^{-}+\mathrm{H}^{+} \quad \mathrm{K}_{\mathrm{a}}=\frac{\mathrm{C}_{\mathrm{HS}^{-}}-\mathrm{C}_{\mathrm{H}^{+}}}{\mathrm{C}_{\mathrm{H}_{2} \mathrm{~S}}}
$$

Total sulphide concentration is the sum of dissociated and non-dissociated forms:

$$
\mathrm{C}_{\mathrm{TS}}=\mathrm{C}_{\mathrm{H}_{2} \mathrm{~S}}+\mathrm{C}_{\mathrm{HS}^{-}}
$$

Concentration of sulphide in the gas phase under equilibrium conditions can be estimated using Henry's law:

$$
\mathrm{y}_{\mathrm{H}_{2} \mathrm{~s}}=\mathrm{H} \cdot \mathrm{C}_{\mathrm{H}_{2} \mathrm{~s}}
$$

A sulphide mass balance for the reactor can be established:

$n_{S} \cdot V_{E G S B}=F_{E G S B} \cdot C_{T S-E G S B}+G_{\text {biogas }} \cdot y_{H_{2} S-b i o g a s}[4]$

Where $n_{S}$ represents the sulphide generation, which can be evaluated by the sulphate load and removal.

In the presence of a desorption column, mass balances for the reactor and the column have to be considered:

Column

$\underset{\text { balance }}{\operatorname{mass}} \mathrm{F}_{\mathrm{R}} \cdot \mathrm{C}_{\mathrm{TS}-\mathrm{EGSB}}=\mathrm{F}_{\mathrm{R}} \cdot \mathrm{C}_{\mathrm{TS}-\mathrm{C}}+\mathrm{G}_{\mathrm{C}} \cdot \mathrm{y}_{\mathrm{H}_{2} \mathrm{~S}-\mathrm{C}}[5]$

Reactor

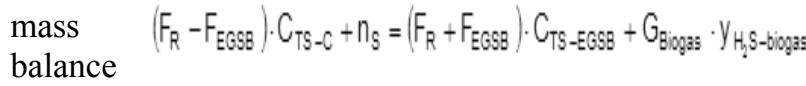


Table 2. Operation periods for the EGSB reactor, with desorption column.

\begin{tabular}{|c|c|c|c|c|}
\hline Operation period & $\mathrm{SO}_{4}^{-2}(\mathrm{mg} / \mathrm{l})$ & $\mathrm{pH}$ & $\mathrm{COD} / \mathrm{SO}_{4}{ }^{-2}$ & $\begin{array}{l}\text { Sulphate loading rate } \\
\qquad(g / L d)\end{array}$ \\
\hline 15 & 900 & 7.5 & 4.7 & 3.6 \\
\hline 16 & 900 & 7.0 & 4.7 & 3.6 \\
\hline 17 & 900 & 6.5 & 4.7 & 3.6 \\
\hline 18 & 1600 & 7.5 & 2.6 & 6.5 \\
\hline 19 & 1600 & 7.0 & 2.6 & 6.5 \\
\hline 20 & 1600 & 6.5 & 2.6 & 6.5 \\
\hline 21 & 2100 & 7.5 & 2.0 & 8.5 \\
\hline 22 & 2100 & 7.0 & 2.0 & 8.5 \\
\hline 23 & 2100 & 6.5 & 2.0 & 8.5 \\
\hline
\end{tabular}

These equations can be combined to obtain the effluent $\mathrm{H}_{2} \mathrm{~S}$ concentration. This concentration would represent the minimum non-dissociated sulphide concentration, since it was evaluated assuming equilibrium considerations. Complete mix behaviour has been assumed for both, column and EGSB reactor. Sulphide equilibrium calculations were performed assuming a pKa of 6.97 (Ebbing, 1996) and a Henry constant of $10.1(\mathrm{~atm} / \mathrm{mol} / \mathrm{L})$
(Perry and Green, 1999).

\section{RESULTS AND DISCUSSION}

Figure 2 presents COD and sulphate removal for each of the conditions tested during the operation of EGSB reactor during phase 1, at the end of each operational period. High sulphate removal levels were attained during all the experimental periods, excluding those for $150 \mathrm{mg} \mathrm{SO}{ }_{4}^{-2} / \mathrm{L}$

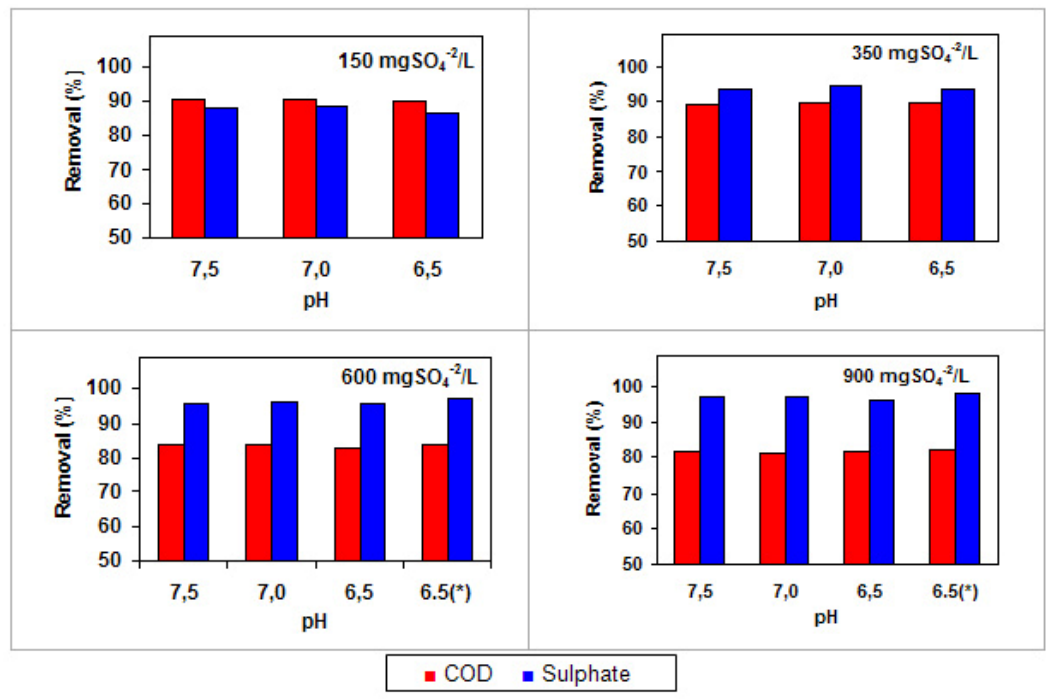

Figure 2. COD and sulphate removal levels during the operation of the EGSB reactor during phase 1 (no desorption column), at different sulphate concentrations. $\left(^{*}\right)$ indicates the operation with a superficial velocity of $8.5 \mathrm{~m} / \mathrm{h}$. 


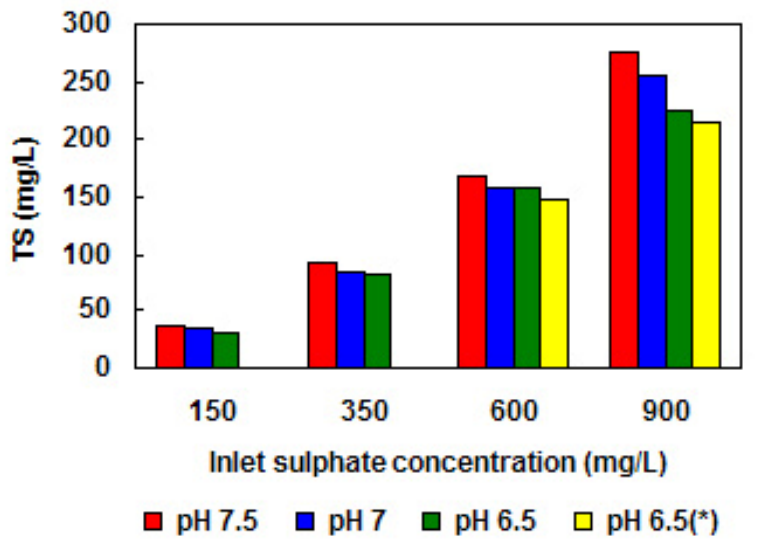

Figure 3. Total sulphide (TS) concentration on EGSB reactor effluent during phase 1 (no desorption column).

that are slightly below $90 \%$. Outlet sulphate concentrations were in the range $10-20 \mathrm{mg} / \mathrm{L}$ for all the tested conditions. COD removal reduced as the inlet sulphate concentration increased. This was produced at a high extent by the increasing sulphide concentration on reactor effluent: sulphide increases the oxygen demand of the treated water, notoriously reducing its quality. Reduction of COD removal showed by Figure 2 is not therefore generated by a decrease in organic matter removal. If effluent COD is corrected considering complete sulphide oxidation during COD analysis (Clescerl et al. 1999), organic matter removal remains practically unchanged during all the experiments.

Figure 3 presents total sulphide (TS) concentration at the end of each operational period. Obviously, total sulphide increases as inlet sulphate concentration rises. The $\mathrm{pH}$ had a slight effect on sulphide concentration: a lower $\mathrm{pH}$ value enhances mass transfer to the gaseous phase due to the increase in the concentration of the non-dissociated form $\left(\mathrm{H}_{2} \mathrm{~S}\right)$. This effect is more noticeable in the $\mathrm{H}_{2} \mathrm{~S}$ biogas concentration, shown in Figure 4. Biogas sulphide

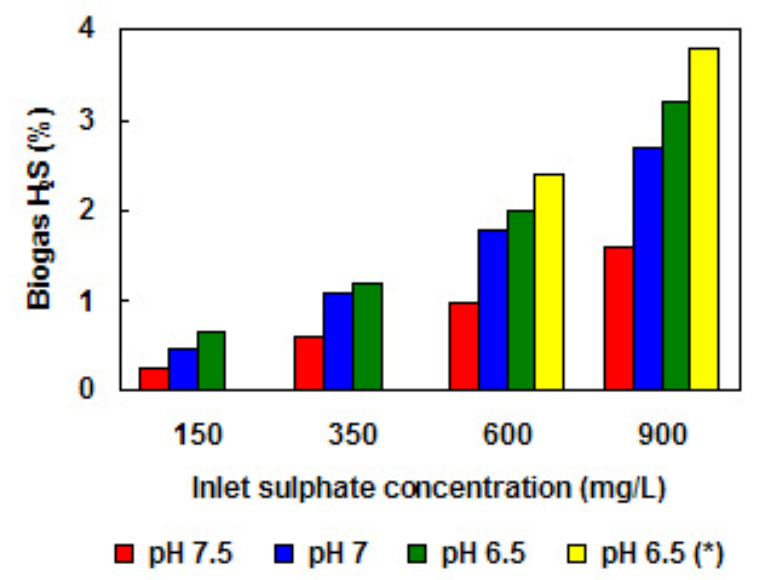

Figure 4. Biogas sulphide concentration during EGSB operation without desorption column (phase 1). concentration is indeed a strong function of the $\mathrm{pH}$ in the range $6.5-7.5$. This happens because most of the produced sulphide leaves the reactor dissolved in the liquid phase, as can be clearly seen in Figure 5. This figure presents the amount of total sulphide that leaves the reactor in the liquid phase, as a percentage of the produced sulphide. Figure 5 shows that under all tested conditions, around $80 \%$ of the sulphide remains in the liquid phase. Therefore, changes in the sulphide distribution between gas and liquid phases will increasingly affect the concentration in the gaseous phase, as was observed. Figure 3, Figure 4 and Figure 5 also show that an increase on the liquid superficial velocity enhances mass transport of $\mathrm{H}_{2} \mathrm{~S}$ to the gas phase, but its impact is not significant in terms of improvement of effluent quality, due to its low effect on effluent TS concentration.

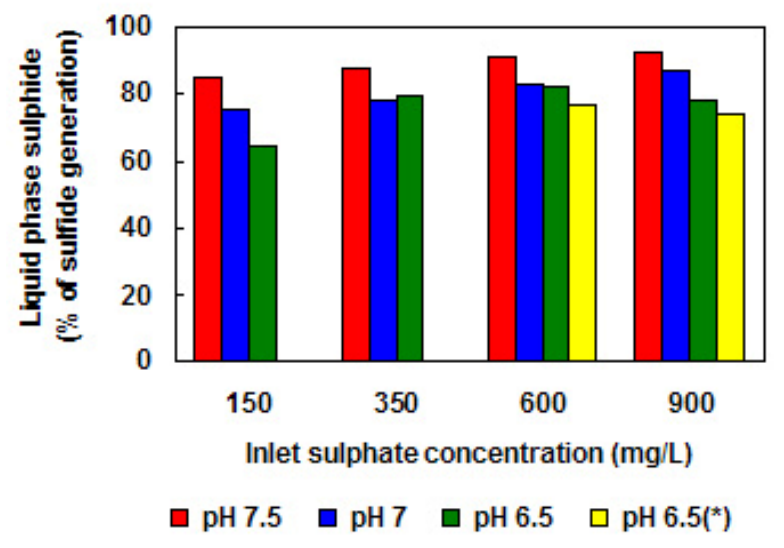

Figure 5. EGSB liquid effluent sulphide content as a percentage of the total sulphide production during phase 1 (no desorption column).

Results show that the liquid-gas mass transfer of sulphide can be enhanced through $\mathrm{pH}$ control, displacing acid-base equilibrium towards non-dissociated sulphide. It should be considered at this point that decreasing the operation $\mathrm{pH}$ may also increase inhibition due to an increment of nondissociated sulphide, which has been reported to take place at concentrations in the range of 50 to $150 \mathrm{mg} / \mathrm{L}$ (Imai et al. 1998). Nevertheless, no inhibition was detected during reactor operation in our study. Unfortunately, $\mathrm{H}_{2} \mathrm{~S}$ transfer is limited by the $\mathrm{pH}$ values that can be safely applied to the biological reactor. A pH lower than 6.5 cannot be imposed without affecting the biological treatment processes. At that condition $25 \%$ of the sulphide is still as $\mathrm{HS}^{-}$, so only $75 \%$ of TS could be eventually transferred to the biogas. Phase equilibrium should also be considered, since it imposes a maximum condition for mass transfer. Figure 6 shows the eventual TS concentration on reactors effluent, if gas-liquid equilibrium conditions for $\mathrm{H}_{2} \mathrm{~S}$ were attained in the EGSB reactor. Calculations have been performed considering the levels of sulphate reduction and biogas production attained during the EGSB operation. Figure 6 shows that even at gas-liquid equilibrium conditions, a high concentration of 


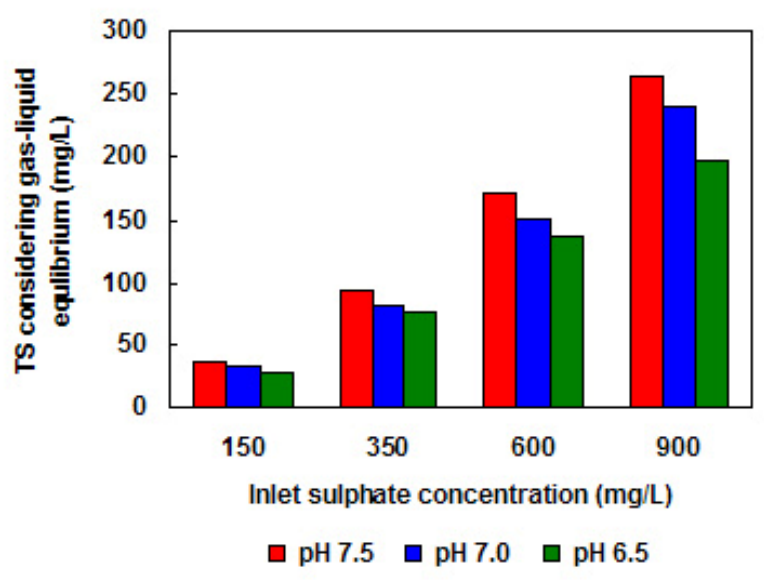

Figure 6. EGSB eventual sulphide concentration at liquid effluent, considering $\mathrm{H}_{2} \mathrm{~S}$ gas-liquid equilibrium conditions in the reactor. Biogas production for calculation was assumed to be the actual production.

sulphide would be present in reactor effluent. Comparison of Figure 3 and Figure 6 shows that sulphide mass transfer rates in the EGSB reactor were significant, since differences between observed and equilibrium conditions were less than $20 \%$.

Therefore, under the conditions of this study (inlet sulphate concentration up to $0.9 \mathrm{~g} / \mathrm{L}$ ), the limitation of anaerobic EGSB reactors to treat high sulphate content wastewater may not related with inhibition considerations, but with low treated water quality due to sulphide content.

An alternative to improve effluent quality by promoting sulphide desorption, is through mass transfer equipment.
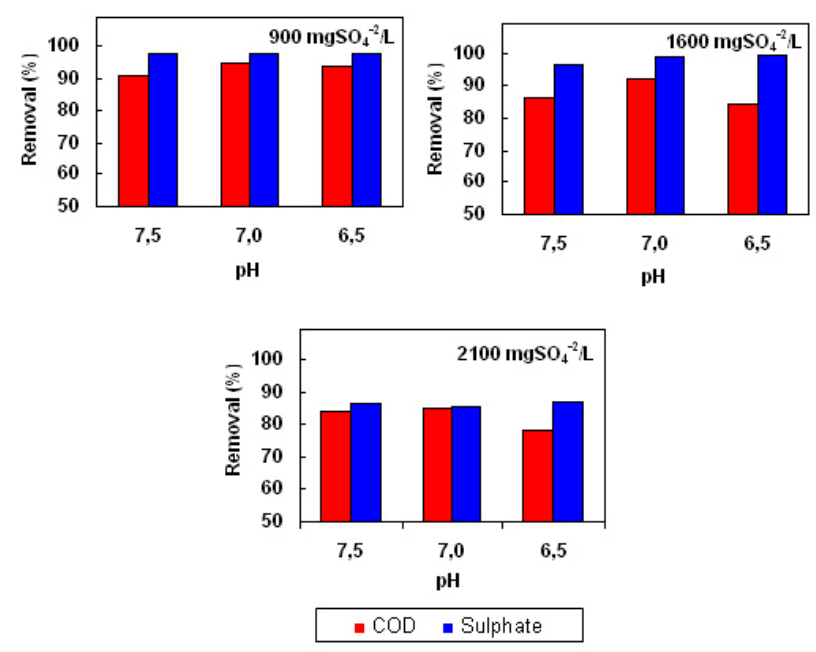

Figure 7. COD and sulphate removals during the operation of the EGSB reactor during phase 2 (in conjunction with a desorption column), at different sulphate concentrations.
During the second phase of the reactor operation, a desorption column was placed in the recirculation line in order to promote sulphide desorption (Figure 1b). Nitrogen was used to simulate the biogas stream that has passed through a physical-chemical step to remove $\mathrm{H}_{2} \mathrm{~S}$. Such a configuration would enhance $\mathrm{H}_{2} \mathrm{~S}$ desorption and promote lower total sulphide concentration in the liquid phase. Figure 7 presents COD and sulphate removals during this operation phase. As during phase 1, COD removal reduces as the inlet sulphate concentration increases, due to higher sulphide content in the effluent. Again, if COD measurements are corrected to eliminate interference of TS, no important reduction in the organic matter removal was observed. Therefore, no noticeable biomass inhibition has taken place. Sulphate removal remains very close to $98 \%$, except for $2100 \mathrm{mgSO}_{4}^{-2} / \mathrm{L}$. Since reactor TS concentrations were similar during operation with 1600 and $2100 \mathrm{mgSO}_{4}^{-2} / \mathrm{L}$, it is inferred that inhibition was not the reason for the reduction in sulphate removal. The reduction is likely to be due to the sulphate load, which during operation periods $21-23$ reached $8.5 \mathrm{kgSO}_{4}^{-2} / \mathrm{m}^{3} \cdot \mathrm{d}$. Then, it is assumed that at the imposed conditions, the sulphate reduction capability of the reactor has been exceeded. Sulphate loading rates attained in the present research are in the same range of those obtained by other authors, also with EGSB reactors. De Smul et al. (1999) reported 80-90\% sulphate removal, at rates of close to $12 \mathrm{gSO}_{4}{ }^{-2} / \mathrm{m}^{3} \cdot \mathrm{d}$, for an EGSB reactor fed with ethanol ad COD source. Dries et al. (1998) obtained similar sulphate removal at a sulphate loading slightly lower, $10 \mathrm{gSO}_{4}^{-2} / \mathrm{m}^{3} \cdot \mathrm{d}$, in an EGSB reactor fed with acetic acid.

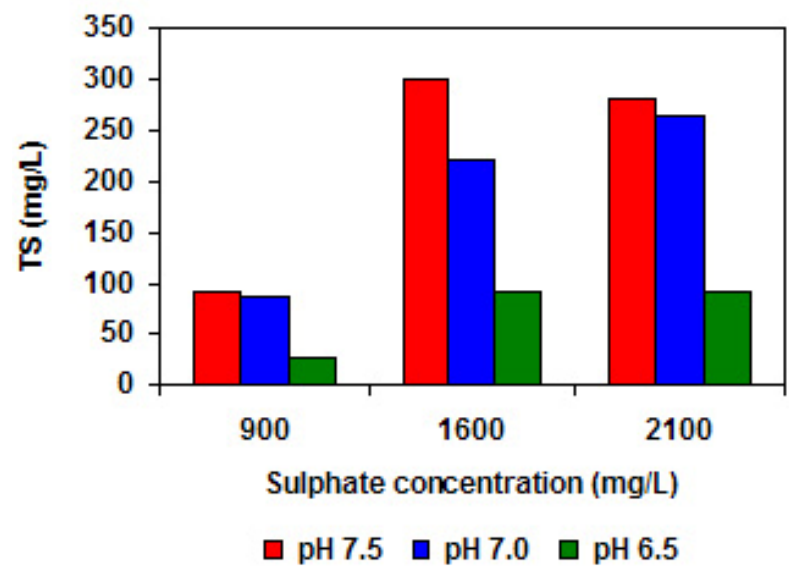

\section{Figure 8. Total sulphide concentration on EGSB reactor effluent during its operation with the desorption column.}

Figure 8 presents the total sulphide concentration on the system effluent (desorption column outlet) during the second phase of the operation. At $900 \mathrm{mg} \mathrm{S_{4 }}{ }^{-2}$ sulphide levels are notoriously lower than those on absent of the mass transfer equipment (Figure 3). However, at higher sulphate concentration (1600 and $2100 \mathrm{mg} / \mathrm{L})$, the column 


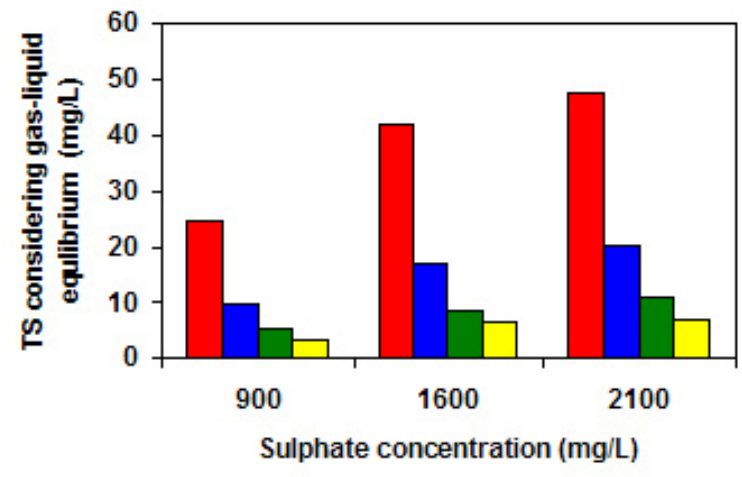

$\square \mathrm{pH} 7.5 \square \mathrm{pH} 7.0 \square \mathrm{pH} 6.5 \square \mathrm{pH} 6.5$ (EGSB), 5.0 (column)

Figure 9. Liquid effluent sulphide concentration assuming $\mathrm{H}_{2} \mathrm{~S}$ gas-liquid equilibrium conditions in the EGSB reactor and the desorption column.

is not capable to provide low levels of sulphide. Figure 9 shows the expected total sulphide concentration at the system effluent for a configuration like the one described, assuming phase equilibrium conditions in both the EGSB reactor and the desorption column. Again, calculations have been performed considering the levels of sulphate reduction and biogas production attained during real operation, a nitrogen flow of $144 \mathrm{~L} / \mathrm{d}$, and the same $\mathrm{pH}$ for the reactor and the desorption column. A situation with different $\mathrm{pH}$ for reactor and column is also considered (6.5 for the reactor and 5.0 for the column). Since these concentrations are based on gas-liquid equilibrium considerations, they represent the theoretical minimum achievable TS levels. Values presented on Figure 9 are quite different from sulphide levels attained during the real system operation (Figure 8). The low performance of the desorption column is probably related with the use of coarse gas diffuser and its small size, which means a low contact time between the phases. Figure 9 also shows that reducing the $\mathrm{pH}$ of the column also improves sulphide mass transfer (under equilibrium conditions).

\section{CONCLUDING REMARKS}

The combined removal of sulphate and organic matter from wastewaters was studied, using an EGSB anaerobic reactor. High sulphate and organic matter removals were attained, with no signal of inhibition up to 2100 and $900 \mathrm{mgSO}_{4}^{-2} / \mathrm{L}$, with and without the desorption unit, respectively. As expected, $\mathrm{pH}$ showed an effect over sulphide distribution in the gaseous and liquid phases, but due to the narrow range of $\mathrm{pH}$ operation that biological wastewater treatment imposes, most of the sulphide is anyway present in liquid effluent reducing treated water quality. The use of an adsorption column to reduce concentration of sulphide improves effluent quality, by reducing notoriously TS concentration in the liquid phase. Optimum design of the column is necessary to increase mass transfer coefficient, in order to achieve an efficient treatment process. If this condition is fulfilled, the proposed system, in conjunction with a sulphide removal step from the biogas, can be successfully used to combine high rate removal of organic matter and sulphate from wastewaters.

\section{REFERENCES}

BUISMAN, C.J.N.; LETTINGA, G.; PAASSCHENS, C.W.M. and HABETS, L.H.A. Biotechnological sulphide removal from effluents. Water Science and Technology, 1991, vol. 24, no. 3-4, p. 347-356.

CLESCERL, Lenore; GREENBERG, Arnold; EATON, Andrew eds. Standard Methods for the Examination of Waters and Wastewaters. $20^{\text {th }}$ edition. Washington DC; American Public Heath Association, 1999. 1325 p. ISBN 0875532357.

DE SMUL, Andy; GOETHALS, Lode and VERSTRAETE, Willy. Effect of COD to sulphate ratio and temperature in expanded-granular-sludge-blanket reactors for sulphate reduction. Process Biochemistry, June 1999, vol. 34, no. 4, p. 407146.

DRIES, Jan; DE SMUL, Andy; GOETHALS, Lode; GROOTAERD, Hans and VERSTRAETE, Willy. High rate biological treatment of sulfate-rich wastewater in an acetate fed EGSB reactor. Biodegradation, March 1998, vol. 9, no. 2, p. 103-111.

EBBING, Darrell. General Chemistry. $5^{\text {th }}$ edition. Boston; Houghton Mifflin, 1996. 1087 p. ISBN 0-395-74415-6.

IMAI, Tsuyoshi; UKITA, Masao; SEKINE, Masahiko; NAKANISHI, Hiroshi and FUKAGAWA, Masayuki. Treatment characteristics of high strength fermentation wastewater consisting of high sulfate and ammonia by UAHB process. Water Science and Technology, November 1998, vol. 38, no. 8-9, p. 377-384.

LETTINGA, G.; FIELD, J.; VAN LIER, J.; ZEEMAN, G. and HULSHOFF POL, L.W. Advanced anaerobic wastewater treatment in the near future. Water Science and Technology, 1997, vol. 35, no. 10, p. 5-12.

LI, Yu-You; LAM, Shirley and FANG, Herbert H.P. Interactions between methanogenic, sulfate-reducing and syntrophic acetogenic bacteria in the anaerobic degradation of benzoate. Water Research, July 1996, vol. 30, no. 7, p. 1555-1562.

MAILLACHERUVU, T.Y. and PARKIN, G.F. Kinetics of growth, substrate utilization and sulfide toxicity for propionate, acetate, and hydrogen utilizers in anaerobic systems. Water Environment Research, 1996, vol. 68, no. 7, p. 10991106.

O'FLAHERTY, Vincent; MAHONY, Thérèse; O'KENNEDY, Ronan and COLLERAN, Emer. Effect of $\mathrm{pH}$ on growth kinetics and sulphide toxicity thresholds of a 
range of methanogenic, syntrophic and sulphate-reducing bacteria. Process Biochemistry, June 1998, vol. 33, no. 5, p. 555-569.

PERRY, R. and GREEN, D. Perry's Chemical Engineers' Handbook. $7^{\text {th }}$ edition, New York; McGraw Hill, 1999. 2640 p. ISBN 0-07-049841-5.

RASKIN, L.; RITTMAN, B.E. and STAHL, D.A. Competition and coexistence of sulfate-reducing and methanogenic populations in anaerobic biofilms. Applied and Environmental Microbiology, October 1996, vol. 62, no. 10, p. $3847-3857$.

RINZEMA, A. and LETTINGA, G. The effect of sulphide on the anaerobic degradation of propionate. Environmental Technology Letters, February 1988, vol. 9, no. 2, p. 83-88.

SPEECE, R. Anaerobic Biotechnology for Industrial Wastewaters. Tennessee; Archae Press, 1996. 416 p. ISBN 0965022609.

VISSER, A.; BEEKSMA, I.; VAN DER ZEE, F.; STAMS, A.J.M. and LETTINGA, G. Anaerobic degradation of volatile fatty acids at different sulphate concentrations. Applied Microbiology and Biotechnology, December 1993, vol. 40 , no. 4, p. 549-556.

WIDDEL, F. Microbiology and ecology of sulfate and sulfur reducing bacteria. In: ZENDER, A. ed. Biology of anaerobic microorganisms. New York, John Wiley \& Sons, 1988, p 459-586. ISBN 0471882267. 